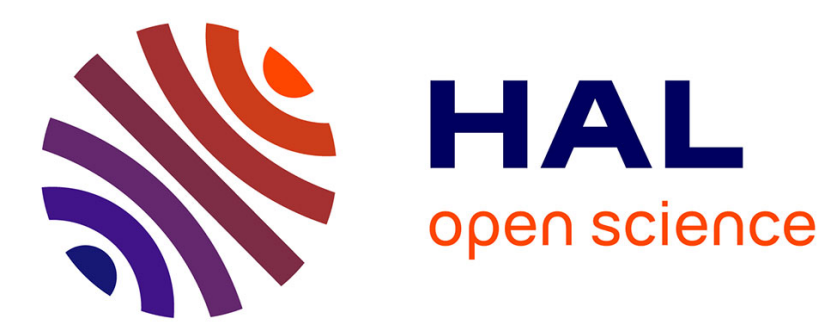

\title{
Historical Roots of the Nonprofit sector in France
}

Edith Archambault

\section{To cite this version:}

Edith Archambault. Historical Roots of the Nonprofit sector in France. Nonprofit and Voluntary Sector Quarterly, 2001, 130 (2), pp.204-230. 10.1177/0899764001302003 . halshs-00118626

\section{HAL Id: halshs-00118626 https://shs.hal.science/halshs-00118626}

Submitted on 5 Dec 2006

HAL is a multi-disciplinary open access archive for the deposit and dissemination of scientific research documents, whether they are published or not. The documents may come from teaching and research institutions in France or abroad, or from public or private research centers.
L'archive ouverte pluridisciplinaire HAL, est destinée au dépôt et à la diffusion de documents scientifiques de niveau recherche, publiés ou non, émanant des établissements d'enseignement et de recherche français ou étrangers, des laboratoires publics ou privés. 


\title{
HISTORICAL ROOTS OF THE NONPROFIT SECTOR IN FRANCE
}

\author{
Edith Archambault, Professor at Paris-Sorbonne University
}

This paper tries to trace the history of the nonprofit organizations in France. French historians have been more interested in the origins of capitalism than in the genesis of the nonprofit sector : more, as far as the more recent period is concerned, few archives of nonprofit organizations have so far been explored and it is the reason why we rely mainly on the work of historians such as Mollat, Agulhon, Gueslin, Vovelle, Zeldin and social scientists such as Tocqueville, Foucault.

We highlight first three long-term trends which have most strongly influenced the development of the nonprofit sector throughout its millennial history:

- the systematic restrictions on nonprofit organizations imposed by a centralized and interventionist state during the 1791-1901 period;

- the early secularization of the nonprofit sector in an old catholic country; due to the French Revolution

- the influence of ideology and of the intellectuals, and especially of the utopian socialism and solidarism, on the whole "social economy", ie cooperatives, mutuals and associations.

Then we outline the historical backgrownd of the French nonprofit sector in the 19 th and 20 th centuries and insist on the most recent period.

\section{I - LONG TERM TRENDS}

\section{I-1 : Etatism, centralization and the nonprofit sector}

Etatism is no doubt the most important feature in French history. The millennian fight of the central State against any form of local power is at the root of the French centralization: fight against feudal order, against urban citizens' organizations during the Middle Ages, fight against regional governments and religious minorities during the Old Regime, fight against the Church and its nonprofit appendices and against guilds during the French Revolution, fight against the labor movement and political clubs during the 19th century. The liberal laws 
at the end of the 19th and at the beginning of the 20th century mark a turning point: the nonprofit sector is no longer illegal, but in the growing centralized state, new forms of social or economic concerns are becoming public concerns while a strong welfare state emerged after WWII in France as in many European countries.

Since the sixties, the trend is to more "laissez faire" and private initiative. More attention is being paid to the tradition of Anglo-Saxon countries. The Decentralization Act (1982) is a way to strive toward a more European political structure; decentralization is recent but it seems to have been a strong incentive to the nonprofit sector development. Reducing the prerogatives of the central government to the benefit of local communities, decentralization have given way to a partnership between nonprofit organizations and local authorities.

\section{I-2 : Secular state and catholic church}

France has always been a catholic country: France as a nation begins with the conversion of Clovis, the leader of the Franks, to the Roman catholic faith. As the "eldest daughter of the Church", the kingdom of France adopted Catholicism as the State religion. Parishes and congregations were at the origin of the most ancient charities: relief to the poor family and children defence and support, sick and elderly people care; schools and other education and research organizations. However, unlike Germany, Belgium or Netherlends, France did not develop a tradition of private action and subsidiarity in spite of the strong influence of the Church. Instead, we observe that very early, especially during the Revolution, the central government replaced the Church in hospitals, asylums and schools.

The consequence of French Etatism is a reverse subsidiarity principle: the nonprofit sector whether religious or secular deals with public concerns which are overlooked by the state. The "eldest daughter of the Church" was indeed also the first to emancipate. Since the Enlightenment period, atheism or free thinking grew more quickly than anywhere else. Nowadays France is the European country where religious observances are the lowest (13\% of the adult population) and stated atheism, the highest (14\%).

Throughout the past, other religions were either tolerated or banned. The emigration of most Protestants after the Edit de Nantes Revocation (1685), the nearly permanent persecution of the Jews and the WWII genocide, have lead to the quasi-monopoly of Catholicism. The dominant religion was threatened, not by other religions, but by a growing atheism and by a widespread indifference toward religion in general. Even the recent rise of islamism in France has challenged the French society more than the Church. The competition 
among religions has not been an incentive to the nonprofit sector, as it has been in AngloSaxon countries.

However, the competition between the catholic church and an active atheism or anticlericalism was, like in Italy, an essential feature throughout the 19th century and still has an impact on the nonprofit sector. The "school war" between catholic and "without god" schools has indeed been constant in France throughout the 19th and the 20th centuries. Though declining, it contrasts with the peaceful relationship between the Church and the state in the field of health and social welfare.

Since the Disestablishment of the Church in 1905, religion is a private concern. This explains why the French nonprofit sector is, except for religious schools, secular, cntrasting with the pillarization system of Germany or Netherlands.

\section{I-3 : The influence of ideology on social economy: Utopian Socialism and solidarism}

A strong socialist tradition is at the origin of a great part of the 19th century nonprofit sector. In contrast with the Marxist influence on the labor movement, utopian socialism was more influent on cooperatives, mutual benefit societies and many other associations. Utopian socialism fought etatism and centralization against the mainstream, and was in favor of mutual societies, self-determination and federalism. Saint Simon, Fourier and mostly Proudhon were the most outstanding intellectuals of this trend.

On the turn of the 20th century, when the modern nonprofit sector and social economy appeared, the official doctrine of the Third Republic, the very basis of its secular ethics was solidarism. The principle of solidarity among the membres of a nation was the rationale of income redistribution; among the members of a professional group, it was the justification of mutual benefit societies.

Obviously, there are strong ideological principles at the root of the nonprofit sector and more generally of the so-called social economy and nowadays we can find either catholic or socialist/solidarist inspiration in many nonprofit organizations or umbrellas.

\section{II - THE FRENCH NONPROFIT SECTOR DURING 19TH CENTURY AND THE FIRST HALF OF 20 TH CENTURY}

The nonprofit sector in France, like in every European country, traces back to the origin of the nation itself. Linked with the Roman Catholic Church, it is older than the 
forprofit sector, the "market society", which progressively emerged in the late Middle Ages and at the beginning of the Renaissance (Braudel 1979).

In France, as everywhere in Europe, the two pillars of the social protection of individuals against proverty and illuness appeared in the Middle Ages : on one hand the charitable organizations linked to the parishes or the monastic orders, hospitals, asylums, orphanages, on the other hand the charitable brother-hoods linked to the guilds which are viewed as ancestors of friendly and mutual societies. The guilds themselves are ancestors of trade-unions and professional organizations. These important institutions in preindustiral societies survived with ups and downs till the French Revolution and a very active civil society was one of the characteristics of the Enlightment Period.

The French Revolution is the great break in the history of the nonprofit sector. It fighted the guilds, and their social subsidiaries, the brotherhoods, as brake to free enterprise and fair competition (Decret d'Allarde, march 1791, Loi Le Chapelier, june 1791). The struggle against the church and congregations had important consequences on their charitable organizations which were either closed or nationalized while the church's property and real estate was seized. Conversely the principle of public primary education and the responsability of government in the eradication of extreme poverty are stated. (F. Ewald 1986). But as no real social policies followed these principles, privates philanthropy was again called for.

In 1810 Napoleon's penal code stated that "any association of over 20 persons, whatever its purpose, cannot be created without the government's agreement and must respect the conditions imposed by public authorities". This restrictive legislation, even reinforced in 1834 , lasted throughout the 19 th century till the 1901 Act gave a still-existing legal status to nonprofit organizations.

\section{II-1 : A bird's eye view of 19 th century non profitsector}

Industrialisation and urbanisation spread in France on a longer period than elsewhere in Europe, with a slower demographic growth. Industrialization and urbanisation lead to the pauperisation of a growing working class. In the absence of labor regulations, sickness, work accidents and unemployment lead to extreme proverty. Despite the prohibition of coalitions, mutual societies, most of which were linked to a clandestine labor movement, survived in clandestine networks. They provided money to the unemployed and to the strikers on a mutual-aid basis.

This prohibited nonprofit sector contrasts with an authorized one. During the constitutional monarchy period (1815-1848), the Catholic Church restored nonprofit organizations in the open and favored the creation of primary and secondary schools. This 
reconstruction was made possible by a public compensation for the previous despoiling of property during the French Revolution. Authorized associations such as the mighty Société philanthropique inspired by freemasonry flourished; they were run by the middle class who created quite a few charitable institutions, such as health centers or meals delivery services (soupes populaires). Besides these charitable organizations, the authorized nonprofit sector included social and recreational clubs intended toward the middle-class, called cercles (Agulhon 1973).

The end of the $19^{\text {th }}$ century is also a period of experimental employers philanthropy. The end of the 19th century is also a period of experimental employers' philanthropy. Some employers, mainly in the textile industry, built housing for their workers and promoted some kind of retirement funds and family allowances. This philanthropic movement was influenced by the social Catholicism stemming from the Rerum Novarum encyclical. For the employers, it was also a way to stabilize and control the workers, since social benefits were lost when the worker went to work in another factory. Le Play was the theoretician of this employers' philanthropic movement and in 1856 he founded the société d'économie sociale. With Charles Gide he promoted social economy during the Universal Exhibitions of 1889 and 1900 in Paris.

The nonprofit sector ceased to be illegal in the late 19th century: the punishment for the crime of coalition, which included strike, was abolished in 1864, and associations revived. The 3rd Republic granted many still-existing civil-rights, and after ten years of parliamentary discussion, labor unions were legalized in 1884 - which is very late compared to what happened in other European countries. This historical fact may explain the weakness of the French trade-unionism: nowadays, the unions are by far weaker in France than in any other European. country.

During this period, mutual-benefit societies dissociated themselves from laborunionism. They became more middle-class oriented and some political leaders used the mutual movement against the labor movement. The 1898 Charte de la Mutualité consecrated this evolution and legalized the mutual benefit societies. The same year (1898) marks the very beginning of the public social policy in France with the vote of a law on industrial injuries and accidents enhancing the employer's liability. As the progressive income taxation which appears at this turning point, all this legislation was inspired by the solidarist current. Solidarism is the official doctrine of the Third Republic, inspired by freemasonry. Under the inspiration of the sociologist Durkheim and the philosopher Bourgeois, solidarity is opposed to individualism and is summed up by the slogan : "Everyone is indebted to his neighbor". The rich especially are indebted to the poor and charity, which is a choice, has to be replaced by solidarity which is a social duty (T. Zeldin, 1973; A. Gueslin, 1987). As Durkheim advocated, solidarity and mutualism are a rehabilitation of intermediate bodies, of 
professional organizations. Solidarity is still a basic principle of social economy and means membership feeling, income redistribution between members and joint liability.

\section{II.2 : The 1901 Law}

The end of 19 th century was a period of anticlerical revival, linked to the Dreyfus Affair and to the competition between the Church and the Republicain State to control education. These conflicts became exasperated at the beginning of 20th century. It is the historical background of the 1901 Act on associations and against the congregations. What was the situation of associations before the 1901 legislation? Three characteristics can be pointed out :

- an administrative authorization was still a prerequisite to found an association of more than 20 members, although exceptions were sometimes made.

- the necessary "state approval" (reconnaissance d'utilité publique), to make the association a legal entity, was sparingly granted.

- a lot of specific statutes exist: labor unions, foreign associations, political clubs, institutions of higher education, social clubs (cercles).

The 1901 Act is the legal consecration of what was already in existence. It defines an association as a "convention according to which two or more individuals permanently put in a common knowledge or activity with another aim in mind than sharing profit". When it has been created, an association may be declared at the préfecture. Undeclared associations have no legal rights. Declared associations have only limited legal rights: they are not allowed to own real estate or to receive legacies. This limited legal capacity was edicted to prevent the Church from passing off parishes or congregations as associations. "State-approved" associations have a full legal capacity and can own real estate and receive legacies. They have to be acknowledged by the Conseil d'Etat after a rather long and restrictive procedure.

The freedom to associate, that is free entrance and free exit into and out of an association, contrasts with the life-long vows of congregation members, considered as an alienation of individual freedom; it is the reason why congregations were excluded from the benefit of the 1901 Act common law. Congregations had to be authorized by the government, like in the previous legislation. The very anticlerical government of Combes ruined and expelled the congregations, suppressed 2,500 unauthorized catholic schools which had been created before 1901, and refused the authorization to open 11,000 schools or hospitals run by congregations.

The war between the state and the Church ended in 1905 with the still-existing legislation of the Disestablishment of the Church: henceforth the catholic religion was no longer the state religion in France as it had been during the past millennium of monarchic 
government. Napoleon's concordat had reestablished them. The Church and the State were legally separated in France and religion became a private concern. In 1905, a specific legislation ruling congregations was edicted and most congregations came back to France.

\section{II.3 : Before and after World War I}

After 1901, many existing nonprofit organizations were legalised but few new social movements were observed. Linked to the Rerum Novarum encyclical, the catholic feminist movement is at the origin of the social work : at the beginning of 20th century, some single middle class women settled in deprived areas and created "social houses" to provide social and legal services to the poor. They also fought for women's liberation in society and the church. The establishment despised them. They were very active during WWI as nurses; a lot of women were enrolled (Guerrand \& Rupp, 1985).

World War I was a turning point for the nonprofit sector, with the growing importance of the Red Cross and other emergency and relief organizations. It was also a melting pot for the various social classes in trench warfare and blood. A growing taxation was accepted to finance the war and the tax burden was not alleviated after the armistice. It was dedicated to the solidarity toward the war victims, such as war damages or veteran allowances. The recovery of Alsace and Lorraine, lost in 1870 and since ruled by German law, created a new problem: those regions benefited from the German social insurance set up by Bismarck (sickness and industrial injuries insurance; retirement and disability pensions). In 1918, France had no social insurance, except for industrial injuries, and had to choose between specific rules for the two newly recovered regions or the generalization of social insurance. Of course, the centralized government chosed the second.

\section{II.4 : The interwar period}

The interwar period was thus the beginning of a state social insurance in France, after the German pattern: compulsory sickness insurance, disability and old age insurance for the low-income salaried employees. The French established family allowances, at the philanthropic employers' suggestion. They were also prompted by a birth rising policy since the birth rate in France had been steadily dropping. During the interwar period, it got below the death rate. During the economic growth in the twenties, there was a manpower shortage due to the death of a lot of young men during the war. A flow of immigrants arrived from Italy, Spain, Belgium, Poland: there were 1,400,000 foreigners in France in 1919 and 3,000,000 in 1930. Many of them became French citizens. The French population became more diversified and the immigrants started creating foreign associations to keep up their specific character and culture. 
WWI was also a period of dirigism and the beginning of inflation in France while the prices had been steady rising throughout the 19th century. Between 1914 and 1920, prices had been multiplied by five and the elderly holding governments bonds were ruined. This new poverty was a concern for charitable organizations since public income-support programs didn't exist. Other forms of new poverty appeared during the Great Depression. The great depression was less severe than in other industrial countries and it was also belated. The peak of unemployment rate reached 20 to $22 \%$ in 1933 in Great Britain and the United States. In France it was around $5 \%$ in 1936. But the unemployment rate was less significant in France because of the importance of agriculture. Farmers were the main victims of the great depression in France as agricultural prices slumped. Social and political tensions were growing; strikes were very long and widespread. Extreme-right leagues and, on the opposite side, anti-fascist organizations came up. The 1936 socialist government of Front Populaire is the result of these political and social tensions. It raised the wages after the 1936 Accords Matignon (general collective bargaining) and regulated the first paid holidays (congés payés).

For the first time, the working class enjoyed a vacation. Léo Lagrange, a minister in the Front Populaire government, was the instigator of a complex network of holiday camps and villages for the working-class families. He also created youth hostels (auberges de jeunesse), and holiday centers for children. This is the origin of "social tourism" in France which is an important part of the nonprofit sector, which developed mainly after WWII.

\section{II.5 : Nazi occupation and Résistance}

World War II was a period of restriction of the freedom to associate. Since 1939, foreigners' associations had to be authorized. This legislation was repealed very late, in 1981, when Mitterrand became President. After the drôle de guerre (phoney war: September 1939May 1940), the defeat and the Occupation of the German army in May 1940, the authoritarian Vichy government of Maréchal Pétain (1940-1944) questioned the 1901 Act: every association could be dissolved by an administrative act (1941). The freemasons and many political organizations were dissolved. On the other hand the Vichy government created a pro-governmental associative network, especially youth organizations. Many forbidden associations were clandestinely reorganized. This clandestine network was a basis for the Resistance movement directed by de Gaulle. At the end of World War II, the 1901 Act was reenacted and all restrictions, with the exception of foreigners' associations, were suppressed. The freedom of association would never be seriously questioned again. 


\section{III - Recent Developments (1945-1995)}

The recent history is characterized by four features : demographic recovery, constant economic growth (lower after 1973), stable republican government participating to the development of the European integration and a growing welfare state, unquestioned despite the recent financial difficulties.

The emergence of a welfare state challenged the existing nonprofit sector

\section{III.1 : Comprehensive social security coverage}

The social security is run by representatives of employers and employees and regulated by the State. Initially intended to the salaried population, the social security scheme previewed an extension to the whole population, that occurred about 1970. A compulsory unemployment insurance run by specific associations, the ASSEDIC, (association pour l'emploi dans l'industrie et le commerce) was created later. From the very beginning, the benefits from social security were an important part of household income: 15\% in 1949 and this relative part increased to $35 \%$ in 1995 .

The creation of the social security scheme questioned the mutual societies, which had been very active in social insurance management since 1930. According to the lawmaker, they had to turn towards mutual aid and management of social actions of the newly created work councils. It was a wrong estimate and mutual societies are still very active in social protection, for two reasons. First, the social security sickness insurance reimbursed health expenses of households but the patient's contribution amounted to $20 \%$ or $30 \%$. This contribution is covered by mutual societies for their members. Similarly, the mutual societies expanded to full income guarantee in case of sickness, accident or death. Second, the extension of social security to the whole population was slower than planned, which explains that some special social security systems are completely run by mutual societies: it is the case for civil servants, students, self-employed people and above all farmers. The case of the farmers is interesting because it is a specific case of delegation of a public service mission to the nonprofit sector: the Agricultural Mutual Society is a completely autonomous social security, mainly financed by fiscal income. The Agricultural Mutual Society is linked to many associations which are active in rural areas, and subsidizes this associative network.

Mutual societies were not only a complement to social security. They were and still are very active in the field of medical and social prevention. Drug and alcoholism prevention, birth control, regular medical check-ups, poliomyelitis or tuberculosis prevention, and now AIDS prevention, are fields where mutual societies and associations were first; social security 
followed. In the post-war period, mutual societies also began to run health and social establishments, mainly for the handicapped and for the elderly.

The post-war period was the peak of the Communist Party in France; it was also the climax of labor unions, and especially of the main union, the CGT (Confédération Générale du Travail), linked to the Communist Party. The modern legislation on employment and work, traces back to this period. The work councils (comités d'entreprise) were created in 1946: these councils, run by representatives of the labour unions elected by employees on labor union lists, are compulsory when a company has more than 50 employees. They are financed by the $1 \%$ off the wage bill contribution of the employers. Works councils manage canteens, day-care and holiday centers for the workers' children, social services for the families. Lately they have become very active in the democratization of culture and of the arts and more recently they manage training and employment programs.

\section{III.2 : The fifties : Catholic Revival and Decolonisation}

The post-war period is also a period of catholic revival in France, specially concerned with youth, working-class and peasantry. Many catholic youth associations, such as Jeunesse Agricole Chrétienne (J.A.C.), Jeunesse Etudiante Chrétienne (J.E.C.), were created in the interwar period and were very active in the post-war period. The influence of J.A.C. on the modernization of agriculture was decisive and many leaders of those youth organizations became politicians, labor union or business associations leaders. Some priests became workers; those priest-workers, condemned by the Pope, were very influent on the catholic youth organizations, especially on the J.O.C. (Jeunesse Ouvrière Chrétienne). A concern with the Third World and decolonization is characteristic of most young people involved in this catholic revival.

In the fifties, the French colonial empire collapsed. The first Independence War broke out in Indochina. Run by a professional army, it had a moderate impact on the French population, but the defeat of Dien Bien Phu (1954) shocked public opinion. The same year, the Independence War broke out in Algeria; it lasted for eight years. 1,500,000 French people were then living in Algeria and the whole contingent fought against the Algerian nationalists. This decolonization war had a great impact on the French population, like the Vietnam war did on the Americans. A lot of organizations, some for the war, others against it, flourished. The economic and political consequences of this war caused the end of the 4th Republic and are at the origin of de Gaulle's come back.

When he came back in power, de Gaulle changed the constitution in order to establish a more steady political regime. The new and still existing constitution was voted by a large 
majority and de Gaulle was the first President to be elected. He ended the Algerian war with difficulty and decolonized peacefully the African empire.

\section{III.3 : The sixties and the seventies : Consumption society, 1968 and the aftermath}

In the sixties, when the colonial wars ended, economic prosperity grew and inflation slowed down. Step by step, the working class caught-up with the consumption pattern of the middle class

With the rejuvenation of the population, its enrichment and higher level of education, the growing participation of women to active life and the change in family patterns, new concerns appeared in society and gave rise to new forms of associations which multiplied in the mid-sixties: environment defence and protection, feminism, notably focused on the fight against birth control restrictions and abortion prohibition support for international development and Third World countries.

The climax of these new concerns was of course the very brief but very important May 1968 movement. In the smoky atmosphere of the "on strike" universities, the students movements were developing days and nights these new topics as well as criticizing the "consumption society" and the organization and teaching methods in higher education ${ }^{1}$. Workers, white collar workers and young executives came out two weeks later and a general strike paralyzed the whole economy for one month. The movement ended late in June with an important wage rise after a collective bargaining, a burst of the right wing middle-class on de Gaulle's impulse and new parliamentary elections. One year later, de Gaulle left the power after a negative referendum. Five years later the international oil crisis occurred.

After the 1968 events, the government tried to reintroduce an authorization for political extremist associations, but the 1971 Act, voted by the Parliament, was cancelled by the Conseil Constitutionel, the French supreme court, as being against the constitutional rule which includes the freedom of association.

More traditional nonprofit organizations expanded during this decade : health and welfare establishments and services multiplied both in the public and the private sector. Parents-teachers associations had to be represented in national education and developed. The first Secretary of Culture, the famous writer Andre Malraux, encouraged the creation of the Maisons de la Culture, multipurpose culture and art centers, and the Maison des Jeunes et de la Culture, culture and recreation facilities intended for the youth; most of these still existing

\footnotetext{
${ }^{1}$ It was the author's first year of teaching and one of her best memory.
} 
organizations are 1901 Act associations and they benefit from important public subsidies. The aim of this cultural network was to democratize and decentralize culture, especially visual and performing arts. However, the public consist mostly of middle-class people and the supremacy of Paris in the cultural activity remains.

In 1971, Jacques Delors proposed a bill, voted by a large majority, to promote continuing education. A special tax on the wage bill subsidizes continuing education schemes run either by forprofit, nonprofit or public establishments. Therefore many associations were created in the seventies; to deliver training and continuing education the competition between establishments benefited mainly private organizations, either nonprofit or forprofit. Nowadays, one employee out of four benefits each year from one form of training or another.

During the sixties and the seventies, France began to catch up in the development of nonprofit sector. New concerns, a more active "civil society", financial public encouragement and favourable regulations explain this evolution. This trend was also reinforced by the action of some civil servants, such as François Bloch-Lainé, who advocated a less statist government by strengthening the nonprofit sector (Ullmann, 1993).

\section{III.4 : The Eighties : Socialist Government and Decentralization}

This tendency was reinforced in the eighties. From a political point of view, this period is characterized by two main features, the first long-term left government and the 1982 decentralization Act. Paradoxically, in this period, we can observe a collapse of the Communist Party, previewing the general collapse of communism in Eastern Europe and a rise of an extreme right wing party, the Front National.

The socialist government encouraged Social Economy organizations, cooperatives, mutual benefit societies and associations, by giving subsidies, fiscal incentives and taxdeductions. They also supported peak organizations in order to encourage the awareness of the unity of social economy.

The 1982 Decentralization Law, which breaks a millenary tradition of centralization, is the second main feature. The State's responsibilities diminished and those of local communities increased. The transfer was progressive and has brought France closer to other European countries. Decentralization stimulated the development of the nonprofit sector: a lot of municipalities and departments delegated some economic or social local policies to associations or shared their new responsibilities with the nonprofit sector. 
From the economic and social points of view, the post-1973 period, in France and elsewhere is characterized by a slower growth rate: $3 \%$ average growth after the first oil crisis, $1 \%$ after the second oil crisis; but the annual growth rate was never negative. The slow growth, joint to the arrival on the labor market of large promotions of baby-boomers, provoked growing and long-term unemployment: the unemployment rate rose from $4 \%$ in 1975 to over $13 \%$ in 1995 .

With less contributions from employers and employees and more unemployment or retirement benefits to pay, the social protection schemes have met constant financial deficits. Moreover, many unskilled young people, especially immigrants' children, are in fact excluded from the labor market and from social benefits linked to employment. Most of them have become "new poor" or dropouts, and the concept of "social exclusion" appeared. During the previous periods, the underprivileged people were mainly the elderly. Nowadays, thanks to social security, to contractual retirement and minimum state pensions, the elderly are welloff or at least not poor; the nonprofit organizations have to adjust to this new poverty.

In deprived industrial areas, such as the northern departments or Lorraine, the nonprofit sector cooperated with local government to provide help and income support to the unemployed new poor. It was the foreshadowing of the minimum income for social integration (RMI) policy, enacted in 1988.

The RMI social policy is important for the nonprofit sector, because nonprofit organizations are considered as vehicles of a public policy. This official acknowledgement follows a long-term de facto cooperation between nonprofit organizations and public authorities, especially in employment policy and health and social activities. Associations help employment policy by running, with important public financing, job-training programs, especially for unskilled workers. They also run hospitals or clinics and nursing homes; most of those belong to the public hospital service and have been funded since 1985 by an overall endowment provided by the health insurance social security. Other nonprofit health establishments have less regulation and negotiate agreements with the social security to benefit third party payments.

A new concern appeared with the rise of the immigration problems. Massive immigration stopped in 1974, but legal entry is possible for people joining their families. Clandestine immigration continues. The recent immigrants, especially Algerians, Moroccans, Tunisians and Black Africans are more different, from ethnic and religious points of view, from the French population, than the Spanish, Portuguese, Italians or Polish of the previous immigration flows. Moreover, their French descendants do not look like the average French citizens. Recent immigrants concentrate in some suburbs which have sometimes become drug and delinquency areas. This is the background of the racist tendencies and of the rise, of Jean 
Marie Le Pen's Front National political party. Some associations are linked to the Front National and their official aim is "national identity defence". According to them, immigration is the root of all current difficulties: unemployment, urban insecurity, drugs and delinquency; To fight racist ideas, some anti-racist associations have been created such as SOS Racisme. In the meantime, with the disappearance, in 1981, of a prior authorization for foreigners' associations, minorities associations have flourished, especially Islamic associations (G. Kepel, 1987); their aim is very often to build mosques in urban suburbs.

With the deepening of the economic depression in the 1990's, the nonprofit organizations intended toward the social integration of long-term unemployed, school dropout and other persons far from the labor market multiplied. Those "intermediary enterprises", often run by a former social worker, are subsidized by the government to compensate the training of the workers, but they also produce marketable goods or services in activities overlooked by standard businesses. Other nonprofit organizations supply temporary work to households, public agencies or other associations. In the recent years, more political organizations appeared also, advocating for the rights of the "without rights" (Action contre le chômage, Droits devant), fighting the globalization and the Washington consensus. The most famous one supports with a climax in Seattle World Trade Organization Conference the Tobin tax against financial speculation (ATTAC, with its 35.000 members). These antiestablishment organizations are at the root of a new extreme-left movement, with international links.

The result of the constant tendency of the nonprofit sector to adjust to the changing issues of the civil society joint to the encouragement of the central and local governments is the association boom of the last three decades. From less than 15,000 in the sixties, the creation of associations went up each year to reach more than 70,000 in 1992. The nonprofit sector is therefore creating jobs while in most industries the number of jobs declined during the last two decades.

With this recent expansion, the French nonprofit sector is bringing France closer to the other European countries in that field, even if historical events have shaped it differently.

\section{CONCLUSION}

This oversimplified survey gives an idea of the very long and deep-rooted history of the nonprofit sector. It took it more than one century to recover after restrictions or prohibitions imposed by the Revolution. However, thanks to its expansion over the last three decades, the nonprofit sector in France is very similar in size to that in the other European 
countries : $5 \%$ of the total employment, 3.3\% of GDP as regarding operating expenditures (Archambault 1997, Salomon and Anheier 1999).

If we revisit now the long-term trends after this overview, we can state that the attitude of the government toward the nonprofit sector shifted from hostility during the 1789-1901 period to a pacific coexistence during the first half of $20^{\text {th }}$ century and an extensive cooperation in the post-war period. This cooperation means public funding $(58 \%$ of total resources of the Nonprofit sector in 1995). Nonprofit organizations are also more and more considered as "social partners" as well as labor-unions in collective bargaining or in the elaboration or implementation of social policies.

Conversely, the Church shifted from direct management of charitable institutions to a moral inspiration on the leaders of most health and welfare organizations. Even the catholic school network secularized. Finally, we find also a socialist or solidarist inspiration in a large part of the French nonprofit sector, especially in the field of education and in mutual societies.

Thanks to its flexibility, the centenary 1901 Act is able to give a form to any collective project, to direct private initiative toward public concerns, to experiment new social institutions intended to new social needs. Involved in many local, national and international networks, the French nonprofit sector is a link in the global civil society.

\section{REFERENCES}

AGULHON, Maurice. 1848 ou l'apprentissage de la République. Paris. Seuil, 1973.

ARCHAMBAULT Edith, The Nonprofit sector in France, Manchester, Manchester University Presse, 1997.

ARCHAMBAULT Edith, "Le secteur associatif en France et dans le monde" in BLOCH-LAINE, Faire société. Les associations au c|lur du social, Paris, Syros, 1999.

BARTHELEMY Martine, Associations, un nouvel âge de la participation, Paris Presse de Sciences Po, 2000.

BRAUDEL, Fernand. Civilisation matérielle, Economie et Capitalisme - XVe - XVIIle siècle, Paris, Armand Colin, 1979.

BRAUDEL, Fernand. L'identité en France, Tome I, Les hommes et les choses, Paris, Arthaud, 1986.

EWALD, François. L'Etat Providence, Grasset, 1986.

FOUCAULT, Michel. Histoire de la folie à l'âge classique. Paris: Gallimard, 1978.

FOUCAULT, Michel. Surveiller et punir, Naissance de la prison. Paris : Gallimard, 1975. 
FURET, François and Mona OZOUF (Ed). Dictionnaire critique de la Révolution Française. Paris: Flammarion, 1988.

GIBAUD, B. De la mutualité à la sécurité sociale. Paris: Editions Ouvrières, 1986.

GUERRAND, R.H. and RUPP, M.A. Brève histoire du service social en France. Paris: Editions Ouvrières, 1969.

GUESLIN, André. L'invention de l'économie sociale, le XIXe siècle français. Paris: Economica, 1987.

KEPEL, G. Les banlieues de I'Islam. Paris: Le Seuil, 1987.

MOLLAT, Michel. Les pauvres au Moyen Age ; étude sociale. Paris: Hachette,1978.

POMEY, Michel. Traité des fondations d'utilité publique. Paris: PUF, 1980.

SALAMON Lester, ANHEIER Helmut et alii, Global civil society, Baltimore, Johns Hoplins University, 1999.

TOCQUEVILLE, Alexis de. De la démocratie en Amérique. 1835. Paris : Gallimard, 1951.

TOCQUEVILLE, Alexis de. L'Ancien Régime et la Révolution. 1856. Paris : Gallimard-Idées, 1964.

ULLMAN Claire, "New social partners : nonprofit organisations and the welfare state in France. Annual meeting of the American Political Science Association, Washington, May 1993.

VOVELLE, M. (Ed). L'Etat de la France pendant la Révolution. Paris: La Découverte, 1988.

ZELDIN Theodor. France 1848 - 1945. Oxford University Press, Ambition, love and politics, 1973 - Intellect, taste and anxiety.

\section{HISTORICAL ROOTS OF THE NONPROFIT SECTOR IN FRANCE}




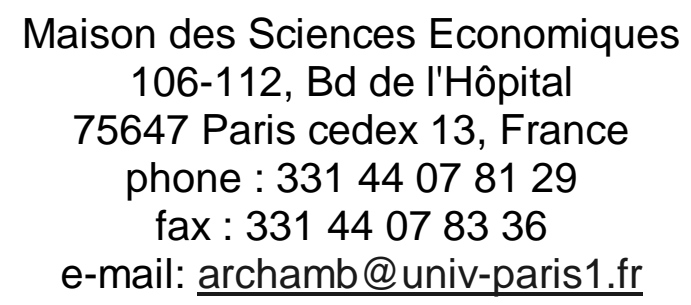

Submitted to Nonprofit and Voluntary Sector Quarterly, special Symposium, décember 2000 


\section{Abstract}

Though deeply rooted in the Middle Ages, as in every European Country, the French nonprofit sector differs in that it was secularized and restricted at the beginning of the $19^{\text {th }}$ century by the centralized state. According to a tradition dating back to the 1789 Revolution, the state had the monopoly of public interest concerns. This tradition gradually lost force in the twentieth century, and nonprofit organizations multiplied during the last three decades in every field of public interest. This trend was encouraged by the central and local governments in a period of decentralization and European integration. Decentralization offers a great opportunity for the French nonprofit sector; conversely, nonprofit organizations provide collective services in an alternative way and can offer an antidote to latent centralization tendencies.

$\underline{\text { Key words }}$ : nonprofit sector, associations, foundations, decentralization, privatepublic partnership, social policies. 
